Функциональное состояние левого желудочка и восходящего отдела аорты при сочетании хронической обструктивной болезни легких и бронхиальной астмы у больных пожилого возраста с артериальной гипертензией

Третьяков С.В.* , Попова А.А., Гребенкина И.А.

ФГБОУ ВО «Новосибирский государственный медицинский университет» Минздрава России

\title{
Functional state of the left ventricle and ascending aorta combined with chronic obstructive pulmonary disease and bronchial asthma in elderly patients with arteriall hypertension
}

Tretyakov S.V.*, Popova A.A., Grebenkina I.A.

Novosibirsk State Medical University

\begin{abstract}
АННОТАЦИЯ
С целью изучения особенностей систолической и диастолической функций левого желудочка в аспекте состояния восходящего отдела аорты у лиц пожилого возраста с артериальной гипертензией и сочетанием хронической обструктивной болезни легких (ХОБЛ) и бронхиальной астмы (БА) обследовано 15 больных мужчин с ХОБЛ и БА (средний возраст $68.4 \pm 3.6$ года). Группу сравнения составили 15 больных ХОБЛ (средний возраст $63.4 \pm 3.2$ года). У всех лиц ХОБЛ категории В. Выявлено, что при сочетании ХОБЛ и БА у лиц пожилого возраста с артериальной гипертензией, в отличие от больных ХОБЛ, отмечается большая степень выраженности концентрической гипертрофии левого желудочка при повышении его контрактильности, в частности, глобальной продольной систолической способности на фоне отсутствия отличий по диастолической его функции и, в частности, продольной.
\end{abstract}

Ключевъе слова: левый желудочек, аорта, сократительная функция, диастолическая функция, восходящая аорта, хроническая обструктивная болезнь легких, бронхиальная астма.

\begin{abstract}
15 male patients with chronic obstructive pulmonary disease (COPD) and bronchial asthma (BA) (average age $68.4 \pm 3.6$ years) are examined for the purpose of studying the features of systolic and diastolic functions of the left ventricle regarding the state of ascending aorta in elderly people with arterial hypertension combined with COPD and BA. A comparison group consisted of 15 patients with COPD (average age $63.4 \pm 3.2$ years). All patients have COPD of B category. It was revealed that elderly people having combined COPD and BA with arterial hypertension, unlike patients COPD, show higher expression of concentric hypertrophy of the left ventricle when rising its contractility, in particular, global longitudinal systolic performance against the lack of differences on its diastolic function and, in particular, longitudinal.
\end{abstract}

Keywords: left ventricle, aorta, contractile function, diastolic function, ascending aorta, chronic obstructive pulmonary disease, bronchial asthma.

\section{В ВЕДЕНИЕ}

Сочетание бронхиальной астмы (БА) и хронической обструктивной болезни легких (ХОБЛ) отмечается примерно у о.16 \% всего населения [1].

\section{INTRODUCTION}

The combination of the bronchial asthma (BA) and chronic obstructive pulmonary disease (COPD) is registered approximately in $0.16 \%$ of all popula-
Поступила 10.04.2018

Принята 20.05.2018

*Автор, ответственный за переписку

Третьяков Сергей Владиславович: ФГБОУ ВО «Новосибирский государственный медицинский университет» Минздрава России. 630091,

г. Новосибирск, Красный просп., 52.

E-mail: ser53953824@yandex.ru
Received 10.04.2018

Accepted 20.05.2018

${ }^{*}$ Corresponding author

Tretyakov Sergey Vladislavovch: Novosibirsk State Medical University, 52, Krasny Prospect, Novosibirsk, 630091, Russia.

E-mail: ser53953824@yandex.ru 
БА выявляется примерно у 5 \% от общего числа больных ХОБЛ, и примерно в 2 раза чаще можно наблюдать случаи ХОБЛ у больных БА [2]. По данным разных авторов артериальная гипертензия выявляется у $1 / 3$ больных БА [3] и у $34.3 \%$ больных ХОБЛ [1]. Хроническое персистирующее воспаление играет важную роль в поражении эндотелия сосудов и развитии атеросклероза у больных ХОБЛ, что, в свою очередь, способствует росту сердечно-сосудистых заболеваний (СС3) (артериальная гипертензия (АГ), ишемическая болезнь сердца (ИБС), острый инфаркт миокарда, сердечная недостаточность) и увеличению риска летальности [4].

При бронхообструктивном синдроме ключевую роль в развитии и прогрессировании АГ играет эндотелиальная дисфункция и хроническое персистирующее воспаление [5]. Молекулярной основой формирования системного воспаления и дисфункции эндотелия (ДЭ) является активация ядерного транскрипционного фактора NF-кB, которая наблюдается при воспалительных процессах в дыхательных путях при БА, атеросклеротическом поражении сосудов и ДЭ при ИБС [6]. Найдена прямая зависимость между выраженностью проявлений дыхательной недостаточности и диастолической дисфункцией левого желудочка (ЛЖ) $[4,7]$. Результаты крупных исследований позволяют предположить, что изменение структурнофункционального состояния стенки аорты играет важную роль в патогенезе СС3 [8]. В ряде проспективных исследований продемонстрировано независимое прогностическое значение показателей центральной гемодинамики и жесткости аорты для общей и сердечно-сосудистой смертности, фатальных и нефатальных коронарных осложнений, несмертельных инсультов у пациентов с неосложненной АГ, сахарным диабетом 2-го типа, терминальной стадией хронической почечной недостаточности, у пожилых больных и в общей популяции [9-11].

\section{ЦЕЛЬ ИССЛЕЛОВАНИЯ}

Изучение особенностей систолической и диастолической функций левого желудочка в аспекте состояния восходящего отдела аорты у лиц пожилого возраста с артериальной гипертензией и сочетанием хронической обструктивной болезни легких и бронхиальной астмы.

\section{МАТЕРИАЛЫ И МЕТОДЫ}

Обследовано 15 больных мужчины с ХОБЛ и БА (основная группа), средний возраст $68.4 \pm$ \pm 3.6 года. Группу сравнения составили 15 боль- tion [1]. BA is revealed approximately in $5 \%$ of the total number of patients with COPD, and it is approximately twice more often possible to observe COPD cases at patients of BA [2]. According to different authors arterial hypertension is revealed in $1 / 3$ BA patients [3] and in $34.3 \%$ of patients with COPD [1]. Chronic persistent inflammation plays an important role in a lesion of endothelium of vessels and atherosclerosis development in patients with COPD that, in turn, promotes the incidence of the cardiovascular diseases (CVD) (arterial hypertension (AH), coronary heart disease (CHD) acute myocardial infarction, heart failure) and to increased risk of mortality [4].

Endothelial dysfunction and chronic persistent inflammation play an essential role in development and advance of $\mathrm{AH}$ at bronchoobstructive syndrome [5]. A molecular basis of formation of systemic inflammation and endothelium dysfunction (ED) is activation of $\mathrm{NF}-\mathrm{\kappa B}$ nuclear transcription factor which is observed at inflammatory processes in respiratory tract with $\mathrm{BA}$, atherosclerotic lesion of vessels and ED at ischemic heart disease [6]. The direct correlation between expression of implications of respiratory failure and diastolic dysfunction of the left ventricle (LV) is revealed [4, 7]. Results of large study suggest that change of a structurally functional state of aorta's wall plays an important role in CVD pathogenesis [8]. An independent prognostic value of indicators of the central hemodynamics and rigidity of aorta for the general and cardiovascular mortality, fatal and not fatal coronary complications, nonfatal strokes in patients with uncomplicated $\mathrm{AH}$, diabetes mellitus type 2, end-stage of chronic kidney disease, in elderly patients and in the general population is presented [9-11] in a number of prospective researches.

\section{AIM OF THE RESEARCH}

Studying of features of systolic and diastolic functions of a left ventricle at ascending aorta in elderly people with arterial hypertension and combined chronic obstructive pulmonary disease and bronchial asthma.

\section{MATERIALS AND MIETHODS}

15 male patients with COPD and BA (the main group) were examined, middle age was $68.4 \pm 3.6$ years. The group of comparison consisted of 15 patents with COPD (middle age $63.4 \pm 3.2$ years). All patients with COPD are of B category. The average value of systolic blood pressure (SBP) in the main 
ных ХОБЛ (средний возраст $63.4 \pm 3.2$ года). У всех лиц ХОБЛ категории В. Средняя величина систолического АД в основной группе составила $154.2 \pm 8.8$ мм рт. ст., в группе сравнения $-156.5 \pm$ \pm 19.9 мм рт. ст. Величина диастолического давления $-83.6 \pm 6.2$ мм рт. ст. у больных основной группы и $86.6 \pm 15.4$ мм рт. ст. в группе сравнения. Критериями исключения из исследования являлись: инфаркт миокарда в анамнезе, фибрилляция предсердий, клапанная патология сердца, сердечная недостаточность III-IV функциональных классов, ожирение II-III степени.

С целью изучения функционального состояния левого желудочка и восходящего отдела аорты проводилось ультразвуковое исследование сердца на аппарате Mindray.

Определяли конечный диастолический объем и размер (КДО, мл; КДР, см), конечный систолический объем и размер (КСО, мл; КСР, см) левого желудочка, фракцию выброса (ФВ, \%), ин-

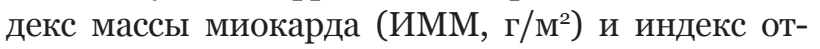
носительной толщины стенки левого желудочка (ИОТ).

Оценка диастолической функции левого желудочка сердца изучалась методом доплерэхокардиографии, которую выполняли в импульсном режиме с использованием верхушечного доступа в четырехкамерной проекции сердца. Определяли следующие параметры: максимальную скорость раннего наполнения (Е, м/с), максимальную скорость предсердного наполнения (A, м/c), их соотношение (E/A), фазу раннего наполнения (FEF, c), фазу предсердного наполнения (FAF, c), механическую диастолу (MD, c), средние скорости раннего и предсердного наполнения (ASE, м/с; ASA, м/c) [12].

Глобальную продольную систолическую и диастолическую функции левого желудочка оценивали по тканевому доплеровскому спектру, зарегистрированному от фиброзного кольца трикуспидального клапана. В каждом тканевом доплеровском спектре определяли $\mathrm{Sm}$ (м/c), $\mathrm{Em}(\mathrm{M} / \mathrm{c})$, $\mathrm{Am}(\mathrm{m} / \mathrm{c})$, соотношения Em/Am и E/Em, продолжительноть фазы изометрического расслабления (IVRT, мc), периода предизгнания (PР, мс) [12].

Из парастернального доступа по длинной оси левого желудочка получали срез восходящего отдела аорты в М-режиме на 2-3 см выше створок аортального клапана. Измеряли конечный систолический диаметр (Ds, cm), конечный диастолический диаметр (Dd, cм), систолическую экскурсию (Ds - Dd, см) восходящей аорты. Рассчитывали показатели эластичности (C - compliance, cм/ дин $\cdot 10^{-6} ; \mathrm{D}-$ distensibility, $\mathrm{cm}^{2} /$ дин $\left.\cdot 10^{-6}\right)$ и ко- group was $154.2 \pm 8.8 \mathrm{~mm} \mathrm{Hg}$, in group of comparison $-156.5 \pm 19.9 \mathrm{~mm}$ Hg. Value of diastolic blood pressure (DBP) $-83.6 \pm 6.2 \mathrm{~mm} \mathrm{Hg}$ in patients of the main group and $86.6 \pm 15.4 \mathrm{~mm} \mathrm{Hg}$ in group of comparison. Withdrawal criteria of the research were the following: myocardial infarction in the anamnesis, auricular fibrillation, valval abnormality of heart, heart failure of the III-IV functional classes, obesity of the II-III degree.

Ultrasound investigation of heart was conducted for the purpose of studying of functional state of the left ventricle and the ascending aorta with the "Mindray" device.

End diastolic volume and dimension (EDV, $\mathrm{ml}$; EDD, $\mathrm{cm}$ ), end systolic volume and dimension (ESV, ml; ESD, cm) of left ventricle, ejection fraction (EF, \%), myocardial mass index (MMI, g/m²) and left ventricular relative wall thickness index (RWTI) were determined.

Assessment of diastolic function of a left ventricle was studied by dopplercardiography that was carried out in pulse sequence with usage of apical access in a four-chamber projection of heart. The following parameters were determined: maximum velocity of early filling ( $\mathrm{E}, \mathrm{m} / \mathrm{s})$, maximum velocity of atrial filling $(\mathrm{A}, \mathrm{m} / \mathrm{s})$, the ratio (E/A), early filling phase (FEF, s), phase of atrial filling (FAF, s), mechanical diastole (MD, s), average velocity of early and atrial filling (ASE, m/s; ASA, m/s) [12].

Global longitudinal systolic and diastolic functions of left ventricle estimated on the tissular doppler spectrum were registered from a fibrous ring of the tricuspid valve. In each tissular doppler spectrum $\mathrm{Sm}(\mathrm{m} / \mathrm{s}), \operatorname{Em}(\mathrm{m} / \mathrm{s}), \mathrm{Am}(\mathrm{m} / \mathrm{s})$, ratio of Em/ $\mathrm{Am}$ and $\mathrm{E} / \mathrm{Em}$, long-lasting isovolumic relaxation time (IVRT, ms), the preejection period (PP, ms) [12] were defined.

A section of the ascending aorta in the M-regimen 2-3 $\mathrm{cm}$ higher than aortic valve cusp was received from parasternal access on a long axis of a left ventricle. Final systolic diameter (Ds, cm), final diastolic diameter (Dd, cm), systolic excursion (Ds $\mathrm{Dd}, \mathrm{cm}$ ) the ascending aorta were evaluated. The following indexed were counted elastance indicators ( $\mathrm{C}$ - compliance, $\mathrm{cm} /$ dyne $\cdot 10^{-6}$; D - distensibility, $\mathrm{cm}^{2} /$ dyne $\cdot 10^{-6}$ ) and coefficients of rigidity of the ascending aorta (SI - stiffness index; Ep - pressure-strain elastic modulus, dyne $\cdot 10^{-6} / \mathrm{cm}^{2}$ ) [1216]. The ascending aorta was visualized on suprasternal view and defined peak rate of systolic antegrade flow (Vps, $\mathrm{cm} / \mathrm{s}$ ) and diastolic retrograde flow $(\mathrm{Vpd}, \mathrm{cm} / \mathrm{s})$, integral rate in systole and diastole 
Таблица 1. Некоторые структурно-функциональные показатели левого желудочка $(M \pm \sigma)$

Table 1. Some structural and functional indicators of the left ventricle $(M \pm \sigma)$

\begin{tabular}{llll}
\hline Показатель / Indicator & ХОБЛ $(n=15) /$ СОРD $(n=15)$ & ХОБЛ + БА $(n=15) /$ СОРD + ВА $(n=15)$ & $p$ \\
\hline КДР, см / EDD, cm & $5.2 \pm 0.71$ & $5.0 \pm 1.1$ & - \\
КСР, см / ESD, cm & $3.5 \pm 0.5$ & $2.8 \pm 0.6$ & - \\
КДО, мл / EDV, ml & $132.0 \pm 2.7$ & $120.0 \pm 7.7$ & - \\
КСО, мл / ESV, ml & $54.0 \pm 1.5$ & $31.6 \pm 1.6$ & $<0.05$ \\
УО, мл / SV, ml & $78.0 \pm 5.5$ & $88.3 \pm 4.1$ & $<0.05$ \\
ФВ, \% / ЕF, \% & $62.0 \pm 2.7$ & $73.3 \pm 3.4$ & $<0.05$ \\
ИОТ / RWТІ & $0.47 \pm 0.42$ & $0.57 \pm 0.61$ & $<0.05$ \\
ИММ, г $/$ м $^{2}$ & $164.7 \pm 2.71$ & $207.7 \pm 5.37$ & \\
ММІ, $/ \mathrm{m}^{2}$ & & & \\
\hline
\end{tabular}

эффициенты жесткости восходящей аорты (SI stiffness index; Ep - pressure-strain elastic modulus, дин $\left.\cdot 10-6 / \mathrm{cm}^{2}\right)$ [12-16]. Из супрастернального доступа визуализировали восходящий отдел аорты и определяли пиковую скорость антеградного потока в систолу (Vps, cм/c) и ретроградного потока в диастолу (Vpd, cм/c), интеграл скорости в систолу и диастолу (VTIs, cм; VTId, см), время ускорения кровотока в систолу и диастолу (ATs, м/c; ATd, м/c) и ускорение кровотока в систолу и диастолу (Acs, cм/ $/ \mathrm{c}^{2} ;$ Acd, cм/ $/ \mathrm{c}^{2}$ ). Рассчитывалась коронарная фракция ударного объема (КФУО, мл).

Полученный цифровой материал был обработан с помощью вариационно-статистических методов путём расчета средней арифметической $(M)$, среднеквадратичного отклонения (б). Различие показателей рассчитывалось методом разностной статистики по критерию Стьюдента и считалось статистически значимым при $p<0.05$ (при $5 \%$ уровне значимости); проводился корреляционный анализ. Использовался коэффициент линейной корреляции Пирсона $r$. Наличие высокой корреляционной взаимосвязи считали при $r=0.87-1,0$.

\section{РЕЗУЛЬТАТЫ И ОБСУЯЛЕНИЕ}

В группе лиц с ХОБЛ + БА, в отличие от больных с ХОБЛ, выявлялось уменьшение КДО ЛЖ на $9.1 \%$ и КСО ЛЖ - на $41.5 \%$ ( $p$ 0.05) на фоне возрастания ударного объема (УО) ЛЖ на $11.7 \%$ $(p<0.05)$, ФВ - на $15.5 \%(p<0.05)$, ИММ ЛЖ на $20.8 \%(p<0.05)$ и ИОТ - на $17.6 \%(p<0.05)$ (табл. 1). Во всех группах отмечалась концентрическая гипертрофия левого желудочка.

Изучение диастолической функции левого желудочка показало, что у больных как основной группы, так и группы сравнения нарушена глобальная диастолическая функция (табл. 2). У лиц с ХОБЛ и БА, в отличие от группы сравнения, хотя и отмечаются более высокие значения макси-
(VTIs, cm; VTId, cm), time of acceleration of a blood flow in systole and diastole (ATs, m/s; ATd, m/s) and acceleration of blood flow in systole and diastole (Acs, $\mathrm{cm} / \mathrm{s}^{2} ;$ Acd, $\mathrm{cm} / \mathrm{s}^{2}$ ). The ventricular stroke volume fraction was evaluated (VSVF, $\mathrm{ml}$ ).

The received digital material was processed by variation and statistical methods calculating the average arithmetic $(M)$, mean square deviation $(\sigma)$. Difference of indicators was counted by method of differential statistics on Student's test and was considered as statistically significant at $p<0.05$ (at $5 \%$ significance value); the correlation analysis was carried out. The Pearson's correlation ( $r$ ) was used. Existence of high correlation interrelation was considered at $r=0.87-1.0$.

\section{RESULTS AND DISCUSSION}

In a group of COPD + BA patients, unlike patients with COPD, the following indicators were revealed: decrease of LV EDV by $9.1 \%$ and LV ESV by $41.5 \%(p<0.05)$ against increasing stroke volume (SV) of the LV for $11.7 \%(p<0.05)$, by EF - for $15.5 \%$ $(p<0.05)$, LV MMI - for $20.8 \%(p<0.05)$ and RWTI - for $17.6 \%(p<0.05)$ (see Table 1). The concentric hypertrophy of a left ventricle was registered among all groups.

Studying of diastolic function of the left ventricle showed that patients of both the main group, and group of comparison have had the disorder global diastolic function (Table 2). Unlike the patients from the group of comparison, patients with COPD and BA have had higher values of the maximum and average rates of flows both in a phase of early filling and the atrial one, however the ratio of peak rates demonstrates the lack of differences in the degree of disturbance in passive filling of the left ventricle between groups. Patients of the main group possess more long atrial filling phase against the lack of differences between groups on duration 
Таблица 2. Показатели диастолической функции левого желудочка $(M \pm \sigma)$

Table 2. Indicators of diastolic function of the left ventricle $(M \pm \sigma)$

\begin{tabular}{llll}
\hline Показатель | Indicator & ХОБЛ $(n=15) /$ COРD $(n=15)$ & ХОБЛ + БА $(n=15) /$ COРD + ВА $(n=15)$ & $p$ \\
\hline E, c | s & $63.0 \pm 0.01$ & $70.92 \pm 0.02$ & $<0.05$ \\
$\mathrm{~A}, \mathrm{~m} / \mathrm{c} \mid \mathrm{m} / \mathrm{s}$ & $70.7 \pm 0.03$ & $78.9 \pm 0.02$ & $<0.05$ \\
$\mathrm{E} / \mathrm{A}$ & $0.89 \pm 0.03$ & $0.89 \pm 0.03$ & - \\
$\mathrm{FEF}, \mathrm{c} \mid \mathrm{s}$ & $262.5 \pm 0.04$ & $284.4 \pm 0.04$ & $<0.05$ \\
$\mathrm{FAF}, \mathrm{c} \mid \mathrm{s}$ & $162.0 \pm 0.04$ & $183.6 \pm 0.04$ & $<0.05$ \\
$\mathrm{MD}, \mathrm{c} \mid \mathrm{s}$ & $475.5 \pm 0.02$ & $477.6 \pm 0.04$ & $<0.05$ \\
$\mathrm{ASE}, \mathrm{m} / \mathrm{c} \mid \mathrm{m} / \mathrm{s}$ & $36.75 \pm 0.07$ & $44.35 \pm 0.09$ & - \\
$\mathrm{ASA}, \mathrm{m} / \mathrm{c} \mid \mathrm{m} / \mathrm{s}$ & $41.67 \pm 0.88$ & $40.3 \pm 0.71$ & - \\
$\mathrm{IVRT}, \mathrm{mc} \mid \mathrm{ms}$ & $97.5 \pm 0.02$ & $91.5 \pm 0.02$ & - \\
$\mathrm{PP}, \mathrm{mc} \mid \mathrm{ms}$ & $99.0 \pm 1.11$ & $102.0 \pm 0.59$ & \\
\hline
\end{tabular}

мальных и средних скоростей потоков как в фазу раннего наполнения, так и предсердного, однако соотношение пиковых скоростей свидетельствует об отсутствии различий в степени нарушения пассивного наполнения левого желудочка между группами. На фоне отсутствия отличий между группами по продолжительности механической диастолы у больных основной группы отмечается более продолжительная фаза предсердного наполнения (на $11.8 \%, p<0.05$ ). В основной группе, в отличие от группы сравнения, происходило незначительное укорочение фазы изоволюмического расслабления на 6.2 \%, т. е. не было замедления удаления ионов кальция из миоплазмы в диастолу и отличий по продолжительности периода предизгнания (по скорости вхождения ионов кальция в миоплазму в систолу) (см. табл. 2).

Данные тканевой доплерокардиографии (табл. 3) демонстрировали более высокие значения Sm, отражающего состояние глобальной сократительной продольной функции левого желудочка, в группе пациентов с ХОБЛ + БА, по сравнению с группой больных ХОБЛ. Sm имеет корреляционную связь с ФВ и величиной УО ЛЖ. Не было отличий между группами по состоянию про- of a mechanical diastole (for $11.8 \%, p<0.05$ ). In the main group, unlike the group of comparison, there was an insignificant shorting of isovolumic relaxation time for $6.2 \%$, i.e. there was no retardation of excision of calcium ions from myoplasm in diastole and differences on preejection period (on the rate of entry of calcium ions into myoplasm in systole) (see Table 2).

Data of tissular dopplercardiography (Table 3) showed higher Sm values, reflecting global longitudinal contractile function of the left ventricle, in group of patients with COPD + BA, in comparison with group of patients with COPD. Sm has correlative relation with $\mathrm{EF}$ and $\mathrm{SV}$ value of the left ventricle. There were no differences between groups on longitudinal function of heart in diastole. At the same time the indicator of $\mathrm{E} / \mathrm{Em}$ was $12 \%$ more in the main group ( $p<0.05$ ) that indirectly demonstrates higher average values of pulmonary artery wedge pressure. Average pulmonary artery wedge pressure (APAWP) was $7.4 \%$ higher in the main group, than the one in the group of comparison (see Table 3 ).

Studying of morphometric indicators of the ascending aorta didn't reveal reliable differences be-

Таблица 3. Показатели продольной глобальной функции левого желудочка $(M \pm \sigma)$

Table 3. Indicators of global longitudinal function of the left ventricle $(M \pm \sigma)$

\begin{tabular}{llll}
\hline Показатель | Indicator & ХОБЛ $(n=15) /$ CОРD $(n=15)$ & ХОБЛ + БА $(n=15) /$ CОРD + ВА $(n=15)$ & $p$ \\
\hline $\mathrm{Sm}, \mathrm{m} / \mathrm{c} \mid \mathrm{m} / \mathrm{s}$ & $23.3 \pm 0.03$ & $27.2 \pm 0.03$ & $<0.05$ \\
$\mathrm{Em}, \mathrm{m} / \mathrm{c} \mid \mathrm{m} / \mathrm{s}$ & $29.14 \pm 0.02$ & $29.06 \pm 0.03$ & - \\
$\mathrm{Am}, \mathrm{m} / \mathrm{c} \mid \mathrm{m} / \mathrm{s}$ & $34.8 \pm 0.005$ & $33.87 \pm 0.005$ & $<0.05$ \\
$\mathrm{Em} / \mathrm{Am}$ & $0.83 \pm 0.04$ & $0.86 \pm 0.05$ & - \\
$\mathrm{E} / \mathrm{Em}$ & $2.14 \pm 0.02$ & $2.43 \pm 0.01$ & $<0.05$ \\
ДЗЛАср, мм рт. ст. & $4.55 \pm 0.12$ & $4.91 \pm 0.14$ & - \\
АРАWР, $\mathrm{mm} \mathrm{Нg}$ & & & \\
\hline
\end{tabular}


Таблица 4. Показатели морфометрии и эластичности восходящей аорты $(M \pm \sigma)$

Table 4. Indicators of morphometry and elastance of the ascending aorta $(M \pm \sigma)$

\begin{tabular}{|c|c|c|c|}
\hline Показатель | Indicator & ХОБЛ $(n=15) / \operatorname{COPD}(n=15)$ & ХОБЛ + БА $(n=15) /$ COРD + ВА $(n=15)$ & $p$ \\
\hline Ds, см $\mid \mathrm{cm}$ & $3.83 \pm 0.16$ & $3.71 \pm 0.21$ & $<0.05$ \\
\hline $\mathrm{Dd}, \mathrm{cm} \mid \mathrm{cm}$ & $3.98 \pm 0.14$ & $3.95 \pm 0.28$ & $<0.05$ \\
\hline Ds - Dd, cм $\mid \mathrm{cm}$ & $0.15 \pm 0.03$ & $0.22 \pm 0.06$ & - \\
\hline $\mathrm{C}, \mathrm{cм} /$ дин $\cdot 10^{-6} \mid \mathrm{cm} /$ dyne $\cdot 10^{-6}$ & $2.21 \pm 0.04$ & $3.32 \pm 0.06$ & - \\
\hline $\mathrm{D}, \mathrm{cм}^{2} /$ дин $\cdot 10^{-6} \mid \mathrm{cm}^{2} /$ dyne $\cdot 10^{-6}$ & $0.95 \pm 1.16$ & $1.29 \pm 0.14$ & - \\
\hline SI & $4.16 \pm 0.07$ & $2.88 \pm 0.14$ & $<0.05$ \\
\hline Ер, дин $\cdot 10^{-6} / \mathrm{cm}^{2} \mid$ dyne $\cdot 10^{-6} / \mathrm{cm}^{2}$ & $0.11 \pm 0.03$ & $0.07 \pm 0.09$ & $<0.05$ \\
\hline $\begin{array}{l}\text { CАД - ДАД, мм рт. ст. } \\
\text { SBP - DBP, mm Hg }\end{array}$ & $50.33 \pm 7.88$ & $50.00 \pm 5.81$ & $<0.05$ \\
\hline
\end{tabular}

дольной функции сердца в диастолу. Вместе с тем показатель E/Em был в основной группе на $12 \%$ больше $(p<0.05)$, что косвенно свидетельствует о более высоких средних значениях давления заклинивания легочной артерии. Среднее давление заклинивания легочной артерии (ДЗЛАср) в основной группе было на 7.4 \% выше, чем в группе сравнения (см. табл. 3).

Изучение морфометрических показателей восходящего отдела аорты не выявило достоверных отличий между группами по конечным систолическому и диастолическому размерам аорты, однако систолическая экскурсия (Ds - Dd) в группе лиц с ХОБЛ + БА была на 31.9 \% больше ( $p$ < 0.05) (табл. 4). Показатели, характеризующие эластичность аорты (C, D), в основной группе были выше, чем в группе лиц с ХОБЛ, на 33.4 и $26.1 \%(p<0.05)$ соответственно, при этом показатели, характеризующие жесткость стенки аорты (SI и Ep), в основной группе были ниже в 1.44 раза $(p<0.05)$ и на $30 \%(p<0.05)$ соответственно.

Изучение показателей антеградного кровотока в восходящей аорте в группе лиц с сочетанной бронхообструктивной патологией не выявило достоверных отличий по пиковой скорости антеградного потока в систолу (Vps) от группы сравнения, однако интегральная скорость антеградного потока в основной группе была выше на $19.3 \%$ $(p<0.05)$ на фоне уменьшения времени ускорения кровотока на $26.1 \%(p<0.05)$ и увеличения ускорения кровотока на $15.2 \%(p<0.05)$ в систолу (табл. 5).

Изучение показателей ретроградного кровотока в восходящей аорте в группе лиц с сочетанной бронхообструктивной патологией выявило увеличение как пиковой скорости ретроградного потока в систолу (Vps) в сравнении с группой больных ХОБЛ, так и интегральной скорости ретроградного потока на $25.8 \%(p<0.05)$ на фоне отсутствия отличий по продолжительности вре- tween groups on the final systolic and diastolic sizes of the aorta, however the systolic excursion (Ds Dd) among patients with COPD + BA was more on $31.9 \%(p<0.05)$ (Table 4$)$. The indicators characterizing elastance of aorta (C, D) in the main group were higher, than in a group of patients with COPD, for 33.4 and $26.1 \%(p<0.05)$ respectively, at the same time the indicators characterizing stiffness of aortic wall (SI and Ep) in the main group were 1.44 times lower ( $p<0.05)$ and for $30 \%(p<0.05)$ respectively.

Studying of antegrade blood flow indicators in the ascending aorta in a group of patients with combined bronchoobstructive pathology did not revealed reliable differences on peak rate of antegrade blood flow in a systole (Vps) in the group of comparison, however the integrated rate of antegrade blood flow in the main group was $19.3 \%$ higher $(p<0.05)$ against the decrease of blood flow acceleration time by $26.1 \%(p<0.05)$ and augmentation of blood flow acceleration at $15.2 \%(p<0.05)$ in systole (Table 5).

Studying of indicators of retrograde blood flow in the ascending aorta in a group of patients with combined bronchoobstructive pathology revealed augmentation as peak rate of retrograde blood flow in systole (Vps) in comparison with group of patients with COPD, and integrated rate of retrograde blood flow for $25.8 \%(p<0.05)$ against the absence of differences on duration of blood flow acceleration time and decrease of acceleration by $35 \%(p<0.05)$ (see Table 5). Changes of retrograde blood flow resulted in augmentation of coronary fraction of stroke flow in the main group, unlike the group of comparison, for $26.8 \%(p<0.05)$.

\section{CONCLUSTION}

Larger intensity of is registered at a combination of COPD and BA in elderly people with arterial 
Таблица 5. Показатели антеградного и ретроградного кровотока в восходящей аорте $(M \pm \sigma)$

Table 5. Indicators of antegrade and retrograde blood flow in the ascending aorta $(M \pm \sigma)$

\begin{tabular}{|c|c|c|c|}
\hline Показатель | Indicator & ХОБЛ $(n=15) / \operatorname{COPD}(n=15)$ & ХОБЛ + БА $(n=15) /$ СОРD + ВА $(n=15)$ & $p$ \\
\hline $\mathrm{Vps}, \mathrm{cm} / \mathrm{c} \mid \mathrm{cm} / \mathrm{s}$ & $88.7 \pm 1.5$ & $92.1 \pm 3.1$ & - \\
\hline VTIs, cм $\mid \mathrm{cm}$ & $15.5 \pm 1.1$ & $19.2 \pm 2.0$ & $<0.05$ \\
\hline ATs, $\mathrm{m} / \mathrm{c} \mid \mathrm{m} / \mathrm{s}$ & $138.0 \pm 8.3$ & $102.0 \pm 4.2$ & $<0.05$ \\
\hline Acs, $\mathrm{cm} / \mathrm{c}^{2} \mid \mathrm{cm} / \mathrm{s}^{2}$ & $651.9 \pm 18.4$ & $768.6 \pm 21.1$ & - \\
\hline $\mathrm{Vpd}, \mathrm{cm} / \mathrm{c} \mid \mathrm{cm} / \mathrm{s}$ & $19.3 \pm 2.4$ & $25.6 \pm 3.2$ & $<0.05$ \\
\hline VTId, см $\mid \mathrm{cm}$ & $4.9 \pm 0.8$ & $6.6 \pm 0.9$ & $<0.05$ \\
\hline $\mathrm{ATd}, \mathrm{M} / \mathrm{c} \mid \mathrm{m} / \mathrm{s}$ & $101.0 \pm 6.5$ & $105.0 \pm 5.8$ & - \\
\hline Acd, $\mathrm{cm} / \mathrm{c}^{2} \mid \mathrm{cm} / \mathrm{s}^{2}$ & $447.2 \pm 34.4$ & $291.1 \pm 28.5$ & $<0.05$ \\
\hline КФУО, мл | VSVF, ml & $60.10 \pm 3.31$ & $82.05 \pm 2.41$ & $<0.05$ \\
\hline
\end{tabular}

мени ускорения кровотока и уменьшения ускорения на 35 \% ( $p<0.05$ ) (см. табл. 5). Изменения ретроградного потока привели к увеличению коронарной фракции ударного потока в основной группе, в отличие от группы сравнения, на 26.8 \% $(p<0.05)$.

\section{ЗАКЛЮЧЕНИЕ}

При сочетании ХОБЛ и БА у лиц пожилого возраста с артериальной гипертензией, в отличие от больных ХОБЛ, отмечается болышая степень выраженности концентрической гипертрофии левого желудочка при повышении его контрактильности, в частности, глобальной продольной систолической способности на фоне отсутствия отличий по диастолической его функции и, в частности, продольной. При сочетании ХОБЛ и БА, в отличие от больных ХОБЛ, у лиц пожилого возраста с артериальной гипертензией отмечается большая степень эластичности и меньшая степень жесткости восходящего отдела аорты, способствующие большей степени депонирования крови в ней и обеспечивающие большую величину коронарной фракции ударного объема при возрастании ударного объема левого желудочка. Увеличение коронарной фракции ударного объема в основной группе также объясняется большей потребностью миокарда в ней из-за роста массы миокарда левого желудочка, что находит свое отражение в увеличении индекса массы миокарда ле-

\section{СПИСОК ЛИТЕРАТУРЫ}

1. Karpov R.S., Vrublevsky A.V., Boshchenko A.A. Stress-ultrasound study of hemodynamic reserve of aortic compression chamber in atherosclerosis: effect on coronary blood flow // Кардиология. 2002. № 1. C. 41-47.

2. Архипов В.В., Прозорова В.К., Архипова Д.Е. Сочетание бронхиальной астмы и хронической hypertension, unlike patients with COPD, in particular, global longitudinal systolic ability against the background of lack of differences on its diastolic function and, in particular, longitudinal one. Unlike the patients with COPD, the high degree of elastance and low degree of stiffness of the ascending aorta is registered in elderly people with arterial hypertension associated with COPD and BA, promoting larger extent of blood storage in it and providing the larger value of coronary fraction of stroke volume when ascending a stroke output of a left ventricle. The augmentation of coronary fraction of stroke volume in the main group is also explained by the greater need of myocardium in it due to the increase of the left ventricular myocardial mass that results in augmentation of the left ventricular myocardium mass index, in a greater degree of intensity concerning concentric hypertrophy of the left ventricle.

Conflict of interest. The authors declare no conflict of interest.

вого желудочка, в большей степени выраженности концентрической гипертрофии левого желудочка.

Конфликт интересов. Авторы заявляют об отсутствии конфликта интересов.

\section{REFERENCES}

1. Karpov R.S., Vrublevsky A.V., Boshchenko A.A. (2002). Stress-ultrasound study of hemodynamic reserve of aortic compression chamber in atherosclerosis: effect on coronary blood flow. Kardiologiia, 1, 41-47.

2. Arkhipov V.V., Prozorova V.K., Arkhipova D.E. (2013). Co-morbidity of bronchial asthma and chronic ob- 
обструктивной болезни легких// Пульмонология. 2013. № 4. C. 87-94.

3. Тарловская Е.И., Одегова А.А. Оценка эффективности медикаментозной терапии в коррекции структурно-функциональных изменений сердечной мышцы у пациентов с артериальной гипертензией в сочетании с бронхиальной астмой // Кардиология. 2016. № 6. С. 36-39.

4. Чучалин А.Г. Хроническая обструктивная болезнь легких и сопутствующие заболевания // Терапевт. арx. 2013. Т. 85, № 8. С. 43-48.

5. Овчаренко С.И., Нерсесян 3.Н., Морозова Т.Е. Хроническая обструктивная болезнь легких в сочетании с артериальной гипертонией: оценка системного воспаления и эндотелиальной дисфункции //Пульмонология. 2015. № 5. С. 561565 .

6. Edwards M.R., Bartlett N.W., Clarke D. et al. Targeting the NF- $\kappa \mathrm{B}$ pathway in asthma and chronic obstructive pulmonary disease // Pharmacol. Ther. 2009. Vol. 121 (1). P. 1-13.

7. Чучалин А.Г., Авдеев С.Н., Айсанов 3.Р. и др. Российское респираторное общество. Федеральные клинические рекомендации по диагностике и лечению хронической обструктивной болезни легких // Пульмонология. 2014. № 3. С. 15-54.

8. Lee H.Y., Oh B.H. Aging and arterial stiffness // Circulation. 2010. Vol. 74. ( 11). P. 2257-2262.

9. Safar M.E., Blacher J., Pannier B. et al. Central pulse pressure and mortality in end-stage renal disease // Hypertension. 2002. Vol. 39 (3). P. 735-738.

10. Safar M.E., O'Rourke M.F. Handbook of hypertension: arterial stiffness and wave reflection. Paris: Elsevier, 2005. 598 p.

11. Willum-Hansen T., Staessen J.A., Torp-Pedersen C. et al. Prognostic value of aortic pulse wave velocity as index of arterial stiffness in the general population // Circulation. 2006. Vol. 113 (5). P. 664-670.

12. Рыбакова М.М., Митьков В.В., Платова М.Л. Комплексная эхокардиографическая оценка систолической и диастолической функции левого и правого желудочков в норме // Ультразвуковая и функциональная диагностика. 2005. № 4. С. 6471.

13. Belz G.G. Elastic properties and Windkessel function of the human aorta //Cardiovasc. Drugs Ther. 1995. Vol. 9 (1). P. 73-83.

14. Bogren Y.G., Mohiaddin R.H., Klipstein R.K. et al. The function of the aorta in ischemic heart disease: a magnetic resonance and angiographic study of aortic compliance and blood flow patterns // Am. Heart J. 1989. Vol. 118. P. 234-247.

15. Chandran K.B. Flow dynamics in the human aorta // Biochem. Eng. J. 1993. Vol. 115. P. 611-616.

16. Klipstein R.H., Firmin D.N., Undewood S.R., Rees R.S., Longmore D.B. Blood flow patterns in the human aorta studied by magnetic resonance // Br. Heart J. 1987. Vol. 58 (4). P. 316-323. structive pulmonary disease. Russian Pulmonology, 4, 87-94. In Russ.

3. Tarlovskaya E.I., Odegova A.A. (2016). Assessment of efficiency of medicamentous therapy in correction of structurally functional changes of the cardiac muscle at patients with arterial hypertension in combination with bronchial asthma. Kardiologiia, 6, 36-39.

4. Chuchalin A.G. (2013). Chronic obstructive pulmonary disease and comorbidities. Therapeutic Archive, $85,8,43-48$.

5. Ovcharenko S.I., Nersesyan Z.N., Morozova T.E. (2015). Chronic obstructive pulmonary disease associated with arterial hypertension: assessment of systemic inflammation and endothelial dysfunction. Russian Pulmonology, 5, 561-565. In Russ.

6. Edwards M.R., Bartlett N.W., Clarke D. et al. (2009). Targeting the NF- $\mathrm{BB}$ pathway in asthma and chronic obstructive pulmonary disease. Pharmacol. Ther., 121, $1,1-13$.

7. Chuchalin A.G., Avdeev S.N., Aysanov Z.R. et al. (2014). Russian Respiratory Society. Federal Guidelines on diagnosis and treatment of chronic obstructive pulmonary disease. Russian Pulmonology, 3, 15-54. In Russ.

8. Lee H.Y., Oh B.H. (2010). Aging and arterial stiffness. Circulation, 74, 11, 2257-2262.

9. Safar M.E., Blacher J., Pannier B. et al. (2002). Central pulse pressure and mortality in end-stage renal disease. Hypertension, 39, 3, 735-738.

10. Safar M.E., O'Rourke M.F. (2005). Handbook of Hypertension: Arterial Stiffness and Wave Reflection. Paris: Elsevier, 598 p.

11. Willum-Hansen T., Staessen J.A., Torp-Pedersen C. et al. (2006). Prognostic value of aortic pulse wave velocity as index of arterial stiffness in the general population. Circulation, 113, 5, 664-670.

12. Rybakova M.M., Mit’kov V.V., Platova M.L. (2005). Complex echocardiographic assessment of systolic and diastolic function of the left and right ventricles in normal condition. Ultrasound and Functional Diagnostics, 4, 64-71. In Russ.

13. Belz G.G. (1995). Elastic properties and Windkessel function of the human aorta. Cardiovasc. Drugs Ther., 9, $1,73-83$

14. Bogren Y.G., Mohiaddin R.H., Klipstein R.K. et al. (1989). The function of the aorta in ischemic heart disease: a magnetic resonance and angiographic study of aortic compliance and blood flow patterns. Am. Heart J., 118, 234-247.

15. Chandran K.B. (1993). Flow dynamics in the human aorta. Biochem. Eng. J., 115, 611-616.

16. Klipstein R.H., Firmin D.N., Undewood S.R., Rees R.S., Longmore D.B. (1987). Blood flow patterns in the human aorta studied by magnetic resonance. Br. Heart J., 58, 4, 316-323. 


\section{СВЕДЕНИЯ ОБ АВТОРАХ}

Третьяков Сергей Владиславович - д-р мед. наук, профессор кафедры поликлинической терапии и общей врачебной практики (семейной медицины) ФГБОУ ВО «Новосибирский государственный медицинский университет» Минздрава России.

Попова Анна Александровна - д-р мед. наук, профессор, заведующий кафедрой поликлинической терапии и общей врачебной практики (семейной медицины) ФГБОУ ВО «Новосибирский государственный медицинский университет» Минздрава России.

Гребенкина Ирина Аркадьевна - канд. мед. наук, доцент кафедры поликлинической терапии и общей врачебной практики (семейной медицины) ФГБОУ ВО «Новосибирский государственный медицинский университет» Минздрава России.

Образец цитирования: Третьяков C.B., Попова А.А., Гребенкина И.А. Функциональное состояние левого желудочка и восходящего отдела аорты при сочетании хронической обструктивной болезни легких и бронхиальной астмы у больных пожилого возраста с артериальной гипертензией // Journal of Siberian Medical Sciences. 2018. № 4. C. 85-93.

\section{ABOUT THE AUTHORS}

Tretyakov Sergey Vladislavovich - Dr. Sci. (Med.), Professor of the Department of Polyclinic Therapy and General Medical Practice (Family Medicine), Novosibirsk State Medical University.

Popova Anna Aleksandrovna - Dr. Sci. (Med.), Professor, Head of the Department of Polyclinic Therapy and General Medical Practice (Family Medicine), Novosibirsk State Medical University.

Grebenkina Irina Arkadyevna - Cand. Sci. (Med.), Associate Professor of the Depaptment of Polyclinic Therapy and General Medical Practice (Family Medicine), Novosibirsk State Medical University.

Citation example: Tretyakov S.V., Popova A.A., Grebenkina I.A. (2018). Functional state of the left ventricle and ascending aorta combined with chronic obstructive pulmonary disease and bronchial asthma in elderly patients with arterial hypertension. Journal of Siberian Medical Sciences, 4, 85-93. 